\title{
Dog Breed
}

National Cancer Institute

\section{Source}

National Cancer Institute. Dog Breed. NCI Thesaurus. Code C53693.

A type of dog known for its special or distinctive characteristics. 